Tourism 2009, 19/1-2

\author{
Bogdan Włodarczyk \\ Łódź University \\ Institut of Urban Geography and Tourism \\ bowlo@poczta.onet.pl
}

\title{
THE LANDSCAPES OF TOURISM SPACE
}

\begin{abstract}
The author attempts to define the term 'tourism landscape'. It is treated as an important attribute of tourism space therefore, apart from its definition, the author presents its characteristic features and various types of such spaces with differing tourism landscapes. The landscapes of tourism space are treated not only as tourism assets or attractions, but also as the consequences of tourism activity on the natural and cultural environment.
\end{abstract}

Key words: geographical space, tourism space, landscape, tourism landscape, landscape of tourism space.

\section{INTRODUCTION}

In geography, landscape is identified mainly with natural elements (geo-complexes). Such a perception (reading) of landscape has been popular ever since the notion was introduced into geography in 1806 by Alexander Humboldt (in KowALCZYK 2007). Therefore it mainly interested physical geographers who stressed connections with the natural environment and its processes, and rarely focused on the relation between the natural environment and man (e.g. RICHLING \& SOLON 1996, 2002, OSTASZEWSKA 2002). This nature-oriented approach was counterbalanced by the notion of cultural landscape, treated as a combination of natural elements and (perhaps above all) the consequences of human activity in nature (KOWALCZYK 2007). The aim of this article is not to discuss the meaning of the term 'landscape', but to answer the question of whether tourism activity can cause changes in the landscape significant enough for it to be called a 'tourism landscape'. If so, what makes it different and what are its characteristic features.

Generally speaking, dictionaries suggest two meanings of the term 'landscape'. The first is literal where landscape is understood as a set of natural and anthropogenic features characteristic of a given area. In other words, landscape is everything we see when looking at an area, i.e. a part of the earth as seen from a given position (Stownik jezzyka polskiego, PWN, 1978, 2007). The other is metaphorical, where landscape is defined as a set of factors creating a given phenomenon, e.g. the political situation forms a political landscape, cultural life - cultural landscape, etc. (Stownik jezyka polskiego, PWN 2007).

In an analysis of 'tourism landscape' both approaches can be used, but in this article the author will consider only the first literal meaning ignoring the metaphorical.

The briefest, and at the same time the most accurate, definition of landscape is that proposed by BOGDANOWSKI (1976) who believes that landscape is a combination of natural and cultural elements forming the 'physiognomy' of the environment (Earth's surface). Adopting this definition for discussion, we may also accept the basic classification of landscapes by the same author:

- primary landscape - capable of self-regulation, its biological balance undisturbed by man;

- natural landscape - partly capable of self-regulation, but containing no important spatial elements introduced as a result of human activity;

- cultural landscape - showing an impaired capability to self-regulate and requiring protection; it is strongly influenced by extensive human activity (see also BOGDANOWSKI et al. 1979).

According to this classification, a 'tourism landscape' can be regarded as a type, or as a part of a cultural landscape. In contrast to 'tourism space', delimited by the presence of tourism, a 'tourism landscape' is a result of various human activities within this space and is perceived in terms of the changes to the natural landscape caused by these activities. A 'tourism landscape' is not usually or 
easily described in isolation. In order to do so, we should need to identify the space where the elements which created it clearly dominate over other components in a cultural landscape.

A question arises as to whether we can talk about a 'tourism landscape' at all. A discussion of landscape terminology, conducted by Plit, shows that authors often excessively form new and questionable terms (e.g. 'sound' landscapes) (PLIT 2007).

$\mathrm{T}$ a b le 1. Types of landscape according to various criteria

\begin{tabular}{|l|l|}
\hline \multicolumn{1}{|c|}{ Criterion } & Type of landscape \\
\hline Origins & $\begin{array}{l}\text { - natural } \\
- \text { anthropogenic }\end{array}$ \\
\hline Topography & - mountainous \\
& - upland \\
& - lowland \\
\hline Natural environment & - forest \\
& - marsh \\
& - desert \\
& - lake \\
& - coast \\
& $-\ldots$ \\
\hline Development & - rural \\
& - urban \\
& - rural-urban fringe \\
\hline Function of geographical space & - agricultural \\
(type of human activity in space) & - industrial \\
& - tourism \\
& $-\ldots$ \\
\hline
\end{tabular}

Sou rce: Author.

The criteria in Table 1 show that a tourism landscape can be treated as one of the types identified on the basis of the main function of a geographical space, measured by the character and intensity of human activity within this space. Thus, using the term 'tourism landscape' seems justified.

\section{THE CONCEPT OF 'TOURISM LANDSCAPE'}

The term 'tourism landscape' is virtually unused in tourism geography, and landscape itself is treated as something that can interest tourists rather than something that can appear as a result of their direct or indirect activity. The terms used most frequently are the 'tourism use of landscape', the 'tourism attractiveness of landscape' (BEZKOWSKA 2003, KOWALCZYK 2007), 'landscape as an element of the tourism attractiveness of an area' (MEYER 2008), 'landscape aesthetics in the context of tourism asset evaluation' (BEŻKOWSKA 2005) or the 'tourist perception of landscape' (KOWALCZYK 1992, 1994). There are also many publications on regional architecture as an element of the cultural landscape of tourism destina- tions (e.g. CHYLIŃSKA 2008, SUCHODOLSKI 2008). Only in the literature in English do we come across the term tourismscape ${ }^{1}$, relating to the actor-network concept which is closer to the assumptions underlying tourism space $^{2}$ than to the classical understanding of the term 'landscape', and largely fits its metaphorical meaning (VAN DER DUIM 2007).

Let us assume then that a 'tourism landscape' is the physiognomy of 'tourism space', a combination of natural and cultural elements as well as of the consequences of tourism activity within this space. This is a general definition and it does not define the balance between the kinds of spaces which create a landscape. If we assume that a tourism landscape can be described as a particular third dimension of tourism space, then we can also speak about a tourism space landscape(s) (WŁODARCZYK 2009). It must be pointed out that we do not mean here only those landscapes perceived or 'consumed' by a tourist, but also those which are a visible consequence of this consumption.

In the first case (landscapes 'consumed' by a tourist), they contain elements which for some reason are interesting for a tourist (natural environment, flora, climate, historical monuments, and less often tourism infrastructure). This kind of landscape, perceived subjectively, can be called a 'landscape of tourism assets (attractions)' and it is typical of exploration, assimilation and, in part, penetration tourism spaces. In the other case we are dealing with landscapes resulting from tourist 'consumption'. In this situation the basic objective delimiting factors are the consequences of tourism-related activity, and its intensity and character point to those spaces of which they are typical (a part of penetration space, and colonization and urbanization spaces). This kind of landscape can be called a 'tourism development landscape'. Because both the subjective and the objective factors are taken into consideration, this division into two kinds of landscapes is not contradictory.

Therefore, we should perhaps present here a definition of tourism activity as an element which helps produce a tourism landscape according to the second approach.

In order to make the terminology we use more precise, let us assume the following:

Tourism activity sensu largo is the ability to be a tourist, to undertake tourism, to be involved in tourism, working on behalf of tourism. Tourism activity sensu largo is not synonymous with actual tourism.

Tourism activity sensu stricto is expressed through active tourism (demanding some involvement e.g. specialised tourism, recreation on summer plots, etc.) (WŁODARCZYK 1999, 2009). 


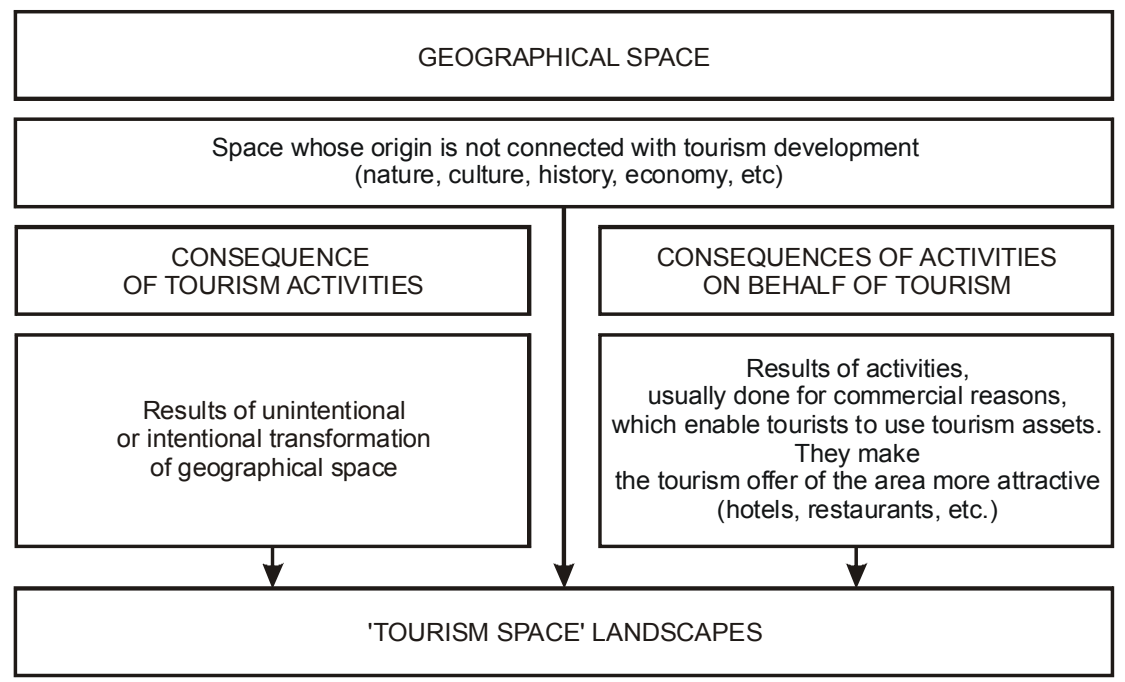

Fig. 1. Elements producing 'tourism space' landscapes (s o u r c e: author)

The requirements of a tourism activity lead to certain events which lead to changes in the space in which the activity takes place. These may cause an unintentional transformation of geographical space, a consequence of the kind of tourism, or they may be an intentional transformation enabling favoured tourism activities to take place (WŁODARCZYK 1999, 2009). Thus, the basic components of 'tourism space' landscapes are elements of the geographical environment (both natural and anthropogenic), the consequences of tourism activities and activities on behalf of tourism.

Tourism activity in space can be divided in three ways:

- Unintentional transformation of geographical space - including tourism activities which do not result in permanent elements of tourism development, but are easily noticeable in the natural environment (paths, roads, tourism trails). These consequences are also evidence of explorative and penetrative activity.

- Intentional transformation of geographical space - including all individual or group activities which aim at adjusting geographical space to recreational needs (e.g. permanent elements of tourism development, tourism settlement - second homes). These activities leave permanent and visible traces in space and may determine the character of a tourism landscape. This kind of activity is typical of tourism colonization space.

- Activities on behalf of tourism are all those individual and group activities (apart from actual tourists themselves) which adjust the environment (geographical space) to the needs of tourism, or which facilitate tourism in a given area in order to achieve pre-planned social or economic goals.
Activities of this kind usually determine the extent to which a natural landscape is transformed and seriously affect the cultural landscape. The 'tourism landscape' they produce is a clearly different and distinctive part of the cultural landscape. The consequences of this kind of activity, of varying intensity and nature, can be observed in all types of 'tourism space' (except exploration). They are most pronounced in tourism colonization space (colonization for tourists), urbanization space and some parts of tourism penetration space (WŁODARCZYK 1999, 2009).

\section{THE FEATURES OF A 'TOURISM LANDSCAPE'}

Assuming that 'tourism space' is a particular kind, or part of, a cultural landscape, we may point to a number of characteristic features:

- it is the third dimension (physiognomy) of 'tourism space'. In other words, it is in the appearance of this space that we can easily identify the consequences (traces) of tourism activity (this space has a particular physiognomy which can be presented on an illustration or photograph). Due to the fact that 'tourism space' is diversified, we may talk about different kinds of 'tourism landscapes' ('tourism space' landscapes). They occupy a part of space and can be presented on a map;

- it shows the development of a given function in geographical space (in this case - the tourism function);

- it is created as a result of removing or (more often) adding elements to the 'pre-tourism' landscape 


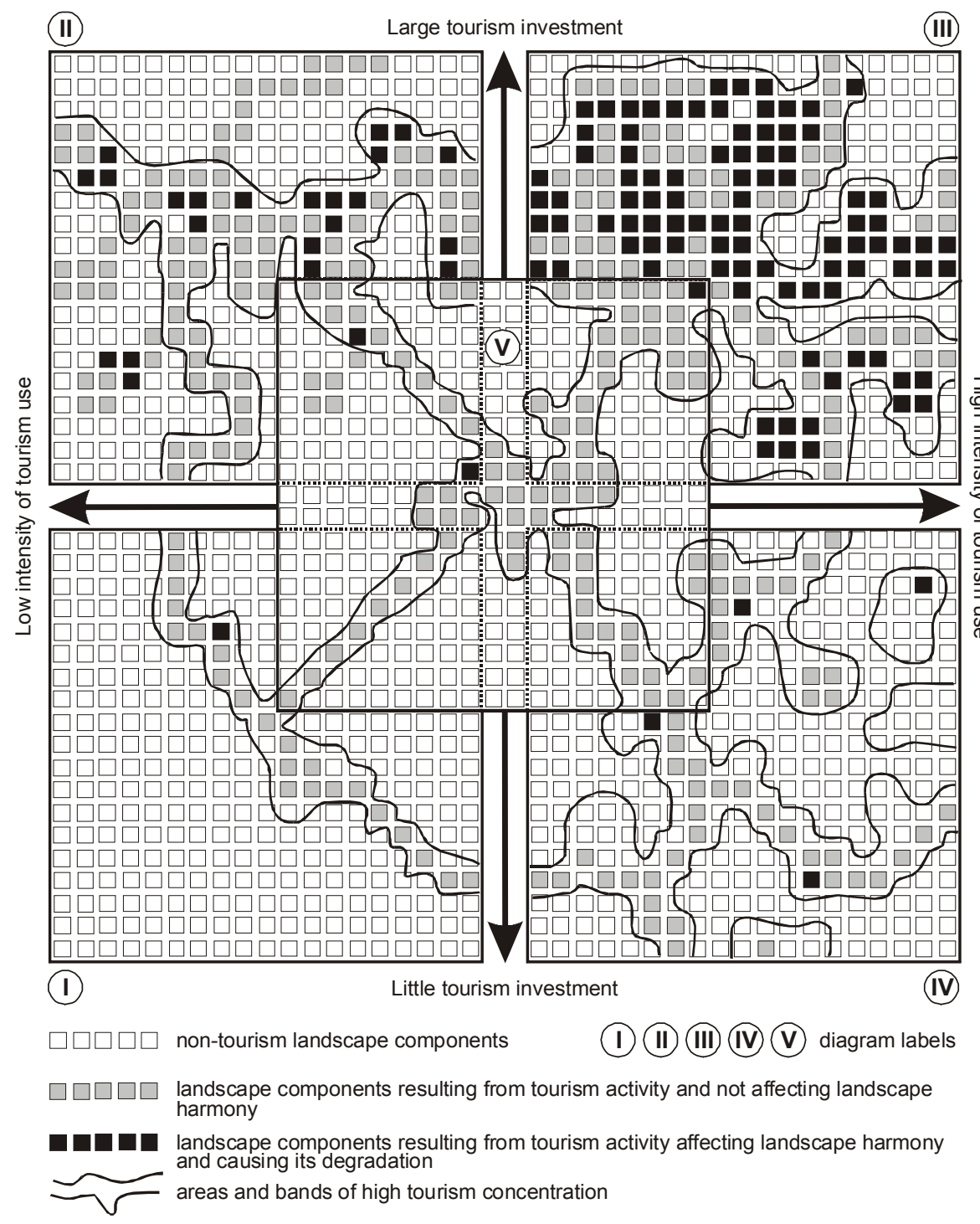

Fig. 2. Spatial types depending on the intensity and character of tourism investment and of actual tourism (in the context of landscape) (s o u r c e: author)

(both natural and cultural) which did not result from the tourism function or activity, which thus becomes another 'layer' of the cultural landscape;

- it is not only consequences but also the cooccurrence of phenomena, thus it cannot be treated as a static and primarily material element (e.g. only from a tourism investment perspective). Man the tourist becomes an important element without which it is difficult to imagine a tourism landscape. It must also be stressed that the earlier ('non-tourism') components of landscape become a part of it, together with the consequences of tourism activity. In other words, it is a dynamic system and its functioning depends on the relations between components and on the main processes (including the nature of human activity);
- it is relative, i.e. it is a consequence of the relation between man the tourist and geographical space (geographical environment), both natural and cultural;

- it undergoes both evolutionary and revolutionary transformation, so it can be said to have its own history;

- it is often perceived through symbols, impressions or values (e.g. Kraków is identified with Wawel, Paris - with the Eiffel Tower, Śnieżka - with the 'flying saucer' refuge, Zakopane - Giewont, Gubałówka and Morskie Oko, Białowieska Forest - bison). 


\section{LANDSCAPE TYPES IN THE CONTEXT OF TYPES OF 'TOURISM SPACE'}

The basis for further discussion will be the first of the features listed above ('tourism landscape' as the physiognomy of tourism space). This physiognomy is affected by both the intensity and the character of tourism investment and of actual tourism, and provides the basis of the tourism space classification presented in Fig. 2:

Type I - with little tourism investment and a low intensity of tourism use. This is reflected in the lack of large building complexes or tourism infrastructure. We can give the example of higher mountains where tourism investment is limited to shelters and tourism trails, and tourism activity (sensu stricto) is limited to exploration and penetration (Photo 1 and 2). They are attractive landscapes due to their naturalness and specificity. Areas of this type are often tourism subecumene ${ }^{3}$ and the tourism landscape can be described as primary.

Type II - with large tourism investment but low intensity of tourism use. They may be landscapes of ageing or old, often 'abandoned', tourism spaces (for example former Olympic centres where huge investments were made in sports and tourism facilities, although after the Games they lost value dramatically, leading to closure or even destruction) (AleJZIAK 2008).

Type III - with large tourism investment and very intensive tourism use. They usually occur in areas where tourism 'absorptiveness' has evidently been exceeded, and tourism infrastructure has dominated the natural components. They are very often disharmonious tourism landscapes ${ }^{4}$ with clear signs of damage or even degradation. Such landscapes are quite common in spaces considered to be the most attractive from a tourism point of view. They are also usually areas of tourism 'monoculture' (the domination of one or several related forms of tourism), mainly recreational. We can give here examples of the coastal landscapes of Languedoc, Florida, California, South Africa, Brazil (Photo 3 and 4), or the Golden Coast in Australia. This type of landscape is less common in mountain areas.

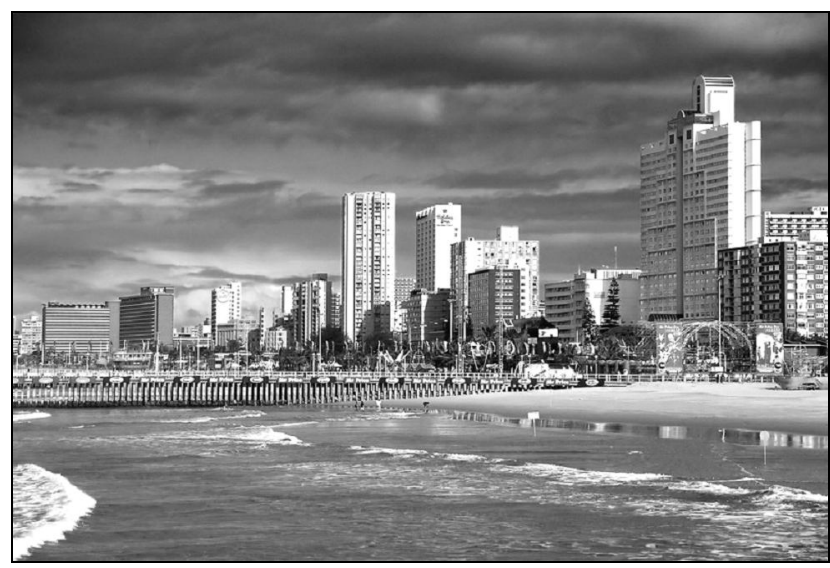

Photo 3. Durban (South Africa) 'tourism space' landscape (s o u r c e: tourism brochure)

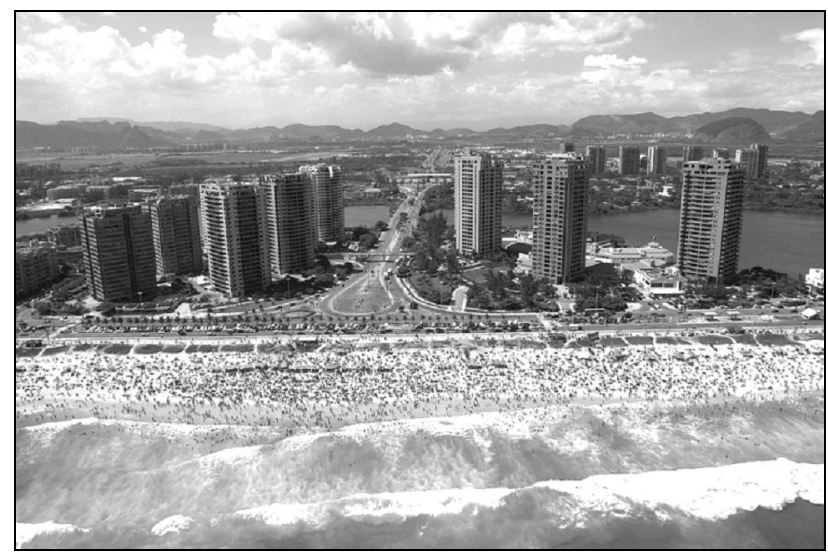

Photo 4. Rio de Janeiro 'tourism space' landscape - a view to the Barra da Tijuca district and beach (s o u r c e: tourism brochure)
Photo 2. Śnieżnik Mountains in Poland - 'Śnieżnik' refuge
Photo 2. Śnieżnik Mountains in Poland
(s o u r c e: author)

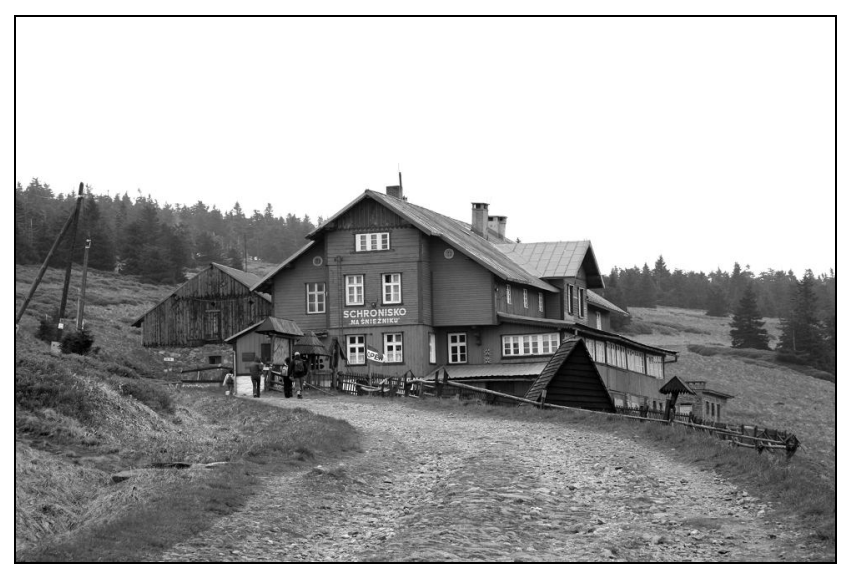

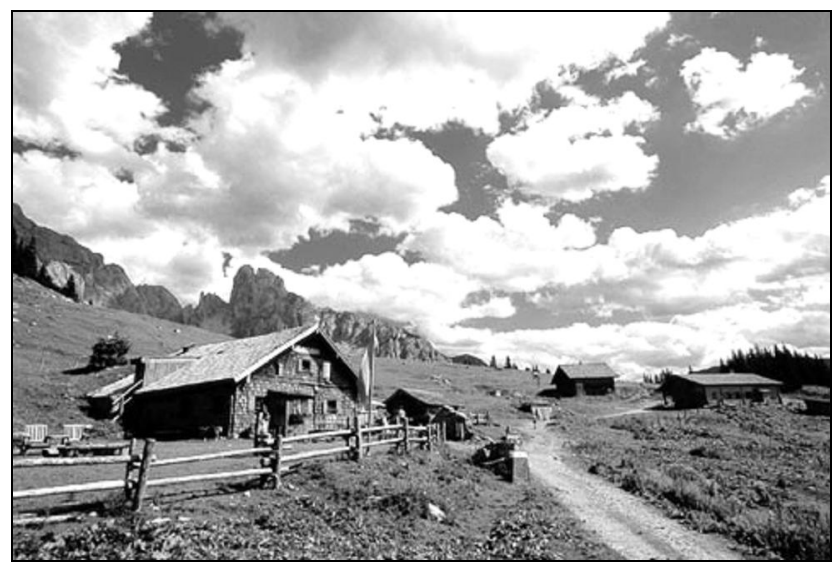

Photo 1. Austrian Alps - refuge on a tourism trail (s o u r c e: author) 
Type IV - with little investment but relatively intensive tourism use. An example of such a landscape can be a national park (especially the most attractive) where despite limitations on building a tourism infrastructure, there are clear negative signs of excessive exploitation of these areas. A similar type of landscape can be found in ski resorts where investment is limited to ski lifts, slopes, and a few hotels and restaurants while the consequences of intensive tourism activity during the winter (visible mainly outside the skiing season) are clearly negative, particularly for the natural components of the landscape (Photos 5-8).

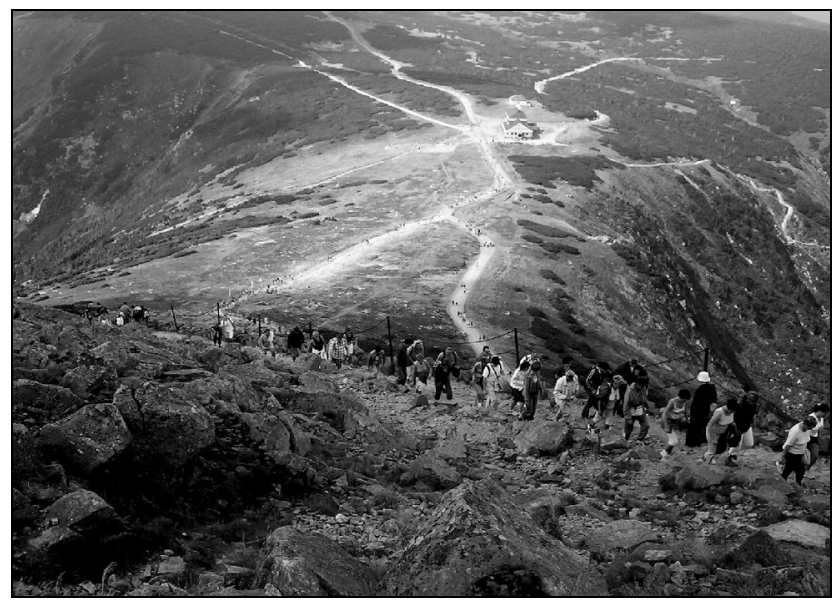

Photo 5. Karkonoski National Park in Poland - a view from Śnieżka to the Dom Śląski refuge; in the background - numerous trails, heavily used during the tourist season

(s o u r c e: author)

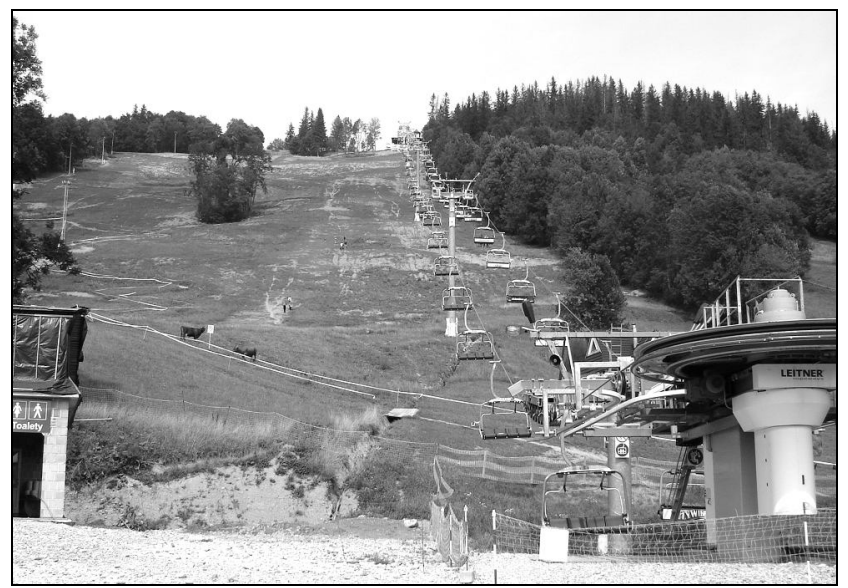

Photo 6. Negative consequences of the heavy use of ski slopes the 'Harenda' skiing and recreational centre in Zakopane in Poland (photo from Ustupski 2007)

Type V - with moderate investment and tourism use which does not lead to natural degradation. The tourism infrastructure of such a space is usually based on local (historical) forms of building or makes use of earlier investment. Tourism observed in this type of landscape is not invasive and is limited mainly to the penetration of the area by means of the existing network of tourism trails. This type of landscape can be called a sustainable or harmonious tourism landscape ${ }^{5}$.

The example which can be given here is the tourism landscape of the Międzygórze resort in the Śnieżnik Mountains, where except for one state 'worker's holiday fund' (FWP) building, the architecture fits in with the $19^{\text {th }} \mathrm{c}$. historical tradition (Photos 9 and 10), and the seasonal, quite intensive tourism is channelled through a well-marked and

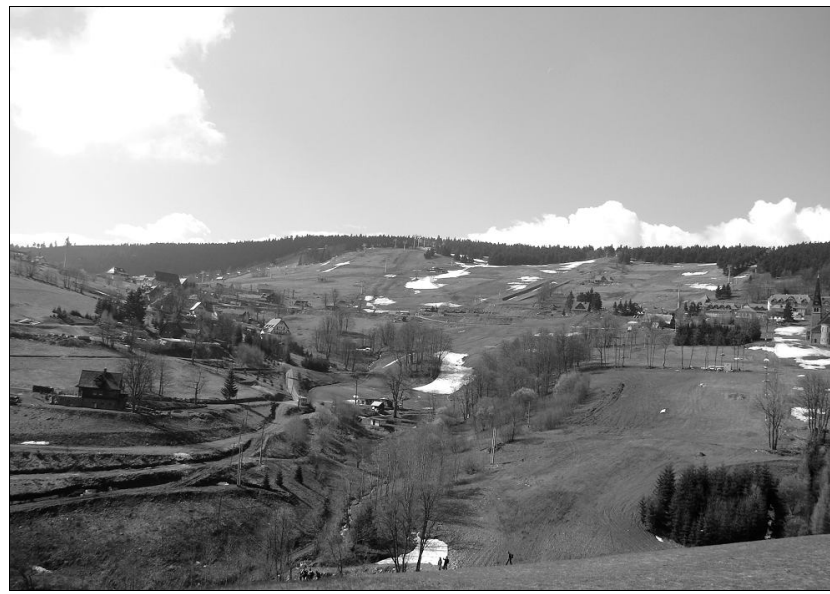

Photo 7. An example of landscape devastation due to excessive skiing tourism - Zieleniec in the Orlickie Mountains in Poland. At the foreground - the effects of modifying the slopes for skiing purposes (s o u r c e: author)

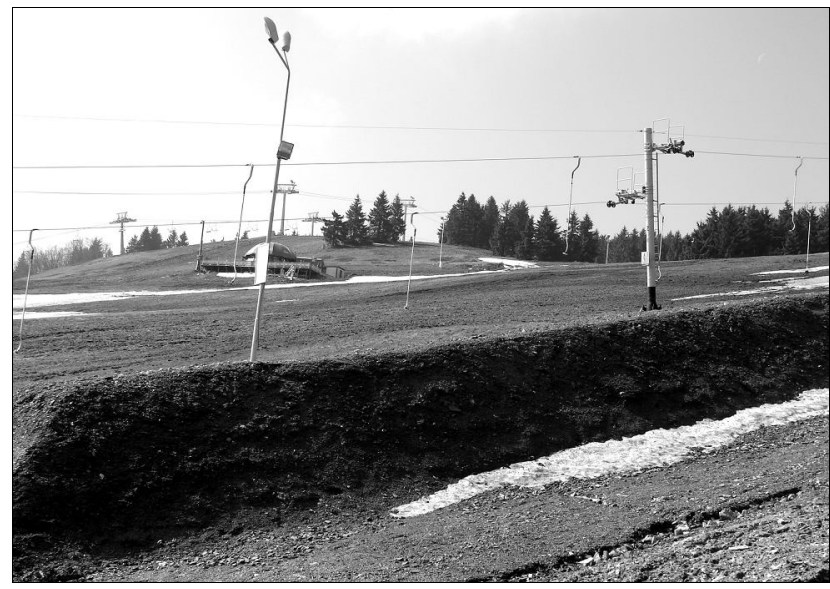

Photo 8. An example of landscape devastation due to excessive skiing tourism - Zieleniec in the Orlickie Mountains; slope erosion (at the foreground - a fragment of a snowboard half-pipe) (s o u r c e: author)

relatively dense network of walking, cycling and skiing trails. Other examples are areas of tourism assimilation and colonization, for instance in the Massif Central in France, where the majority of 


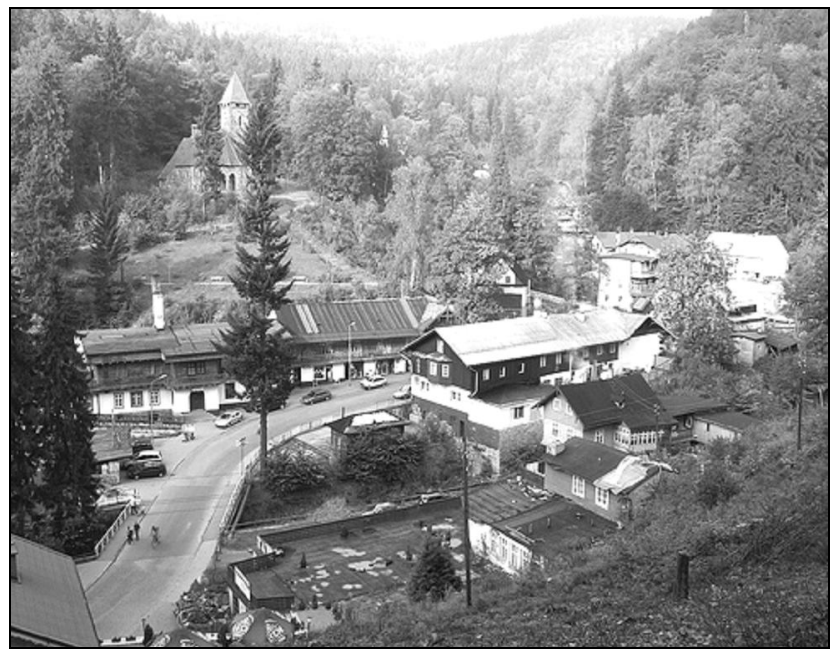

Photo 9. Międzygórze in Poland - an example of harmony in space and landscape (s o u r c e: author)

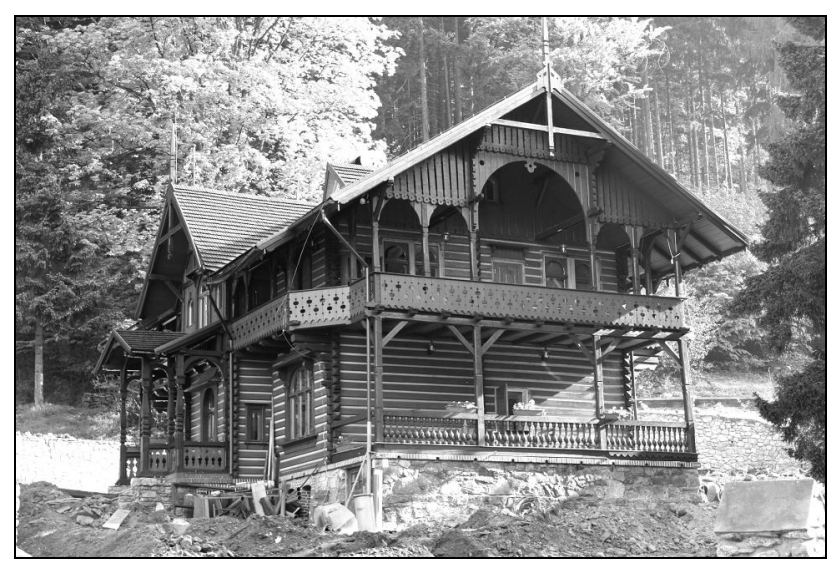

Photo 10. Międzygórze - an example of tourism building from the $19^{\text {th }}$ c. (s o u r c e: author)

second homes are former homesteads preserved in an unchanged regional style.

The types of space presented above (and at the same time the types of landscapes observed in them) may be continuous (i.e. pass from one into another), and the borders between them are often blurred.

\section{CONCLUSIONS}

Similar to 'tourism space', landscapes connected directly are the consequence of changes occurring in geographical space. The changes can be both structural and functional and the landscapes observed in 'tourism space' may be the result of transformations of both the natural environment and as part of a particular continuum of cultural landscape.
If we assume that the use of the term 'tourism landscape' is justified, than we should ask some questions to encourage further research:

- What elements form a 'tourism landscape'? Are they only the consequences of tourism activity or also 'non-tourism' elements variously related to the tourist, and new, usually unfamiliar, components of the tourism infrastructure?

- What kind of relations are they and how strongly do they affect the condition and character of a landscape?

- What is the role of the 'tradition of the site' (tradycja miejsca) and can a 'tourism landscape' reflect this tradition?

- What is associated with a given 'tourism landscape' and why?

- How should a 'tourism landscape' be studied?

We cannot always find overt answers to these and many other questions. Therefore, it seems important to conduct wide-ranging research and consider various approaches and ideas in order to explain the essence, structure and characteristic features of tourism spaces and their landscapes, as well as their development factors.

\section{FOOTNOTES}

1 'Tourismscape' (according to VAN DER DUIM, 2007) is a concept drawn from actor-network theory (ANT) and its highly specific terminology. In Europe the concept was developed by M. Callon, B. Latour and J. Law, who referred to the American conception created by G.Deleuze and M.Foucault. In Polish the theory is also known as "the sociology of non-humans". In the ANT context, tourismscape is not (like cityscape) one of the familiar coinages based on 'landscape', but it also or perhaps first of all has a metaphorical meaning and is perceived as an underlying network of actors and the relations among them, which produce tourism space and what might be known as a tourism landscape. VAN DER DUIM (2007) describes tourismscape as 'relations between people and things' which occur in tourism space. It consists in the incessant changing of those 'processes of association and ordering' which 'allow' tourism to take place.

2 Tourism space is the part of geographical space where tourism takes place. The necessary and sufficient condition for a part of geographical space to be classified as tourism space is tourism, regardless of its scale and nature. An additional condition, which makes delimitation possible, is tourism development whose extent and character define the type of tourism space (WŁODARCZYK 2009).

3 Tourism subecumene - that part of geographical (tourism) space which is used seasonally or incidentally (tourism exploration); its characteristic features are seasonality, lack of continuity and occasional tourism (WŁODARCZYK 2009).

4 A disharmonious landscape (degraded or destroyed) appears when man, due to new activities (including tourist), ignorant or greedy for excessive benefits, destroys the natural balance of the physiocenosis, and causes permanent, progressive, harmful changes that spoil the beauty of the landscape. The characteristic features of such a landscape are heavy industrialization and urbanization, a lack of natural landscape elements, as well as usually requiring regeneration (BOGDANOWSKI 1976).

${ }^{5} \mathrm{~A}$ harmonious landscape occurs when the way it is used fits the character of the natural (geographical) environment (BOGDANOWSKI 1976).

Translated by Ewa Mossakowska 


\section{BIBLIOGRAPHY}

ALEJZIAK, W., 2008, Wielkie wydarzenia sportowe jako czynnik walki konkurencyjnej na globalnym rynku turystycznym, [in:] Turystyka jako czynnik wzrostu konkurencyjności regionów w dobie globalizacji, ed. G. Gołembski, Wydawnictwo Akademii Ekonomicznej w Poznaniu, Poznań, pp. 52-66.

BEZKOWSKA, G., 2003, Możliwości wykorzystania elementów strukturalnych krajobrazu w użytkowaniu turystycznym, [in: Krajobraz - turystyka - ekologia, Problemy ekologii krajobrazu, ed. M. Pietrzak, Państwowa Wyższa Szkoła Zawodowa w Lesznie, Instytut Turystyki - Polska Asocjacja Ekologii Krajobrazu, Leszno, pp. 259-27.

BEZKOWSKA, G., 2005, Znaczenie estetyki krajobrazu w określaniu walorów turystycznych, Turystyka i Hotelarstwo, no. 8, Wydawnictwo WSTiH w Łodzi, Łódź, pp. 43-60.

BOGDANOWSKI, J., 1976, Kompozycja i planowanie w architekturze krajobrazu, Zakład Narodowy im. Ossolińskich, Wydawnictwo PWN, Wrocław-Warszawa-Kraków-Gdańsk, 271 pp.

BOGDANOWSKI, J., ŁUCZYŃSKA-BRUZDA, M., NOVÁK, Z., 1979, Architektura krajobrazu, Państwowe Wydawnictwo Naukowe, Warszawa-Kraków, 246 pp.

CHYLIŃSKA, D., 2008, Harmonia i autentyzm krajobrazu widzianego a wykorzystanie architektury regionalnej i jej cech $\mathrm{w}$ turystyce [in:] Studia krajobrazowe jako podstawa właściwego gospodarowania przestrzenią, eds A. Zaręba, D. Chylińska, Zakład Geografii Regionalnej i Turystyki, Uniwersytet Wrocławski, Wrocław, pp. 221-229.

DUIM, VAN DER R., 2007, Tourismscapes - An Actor-Network Perspective, Annals of Tourism Research, vol. 34, no. 4, pp. 961-976.

KOWALCZYK, A., 1992a, Metodologia i metodyka badań percepcji krajobrazu z punktu widzenia potrzeb turystyczno-wypoczynkowych, Gea, no. 2, Metody oceny środowiska przyrodniczego, pp. 25-36.

KOWALCZYK, A., 1992b, Badanie spostrzegania krajobrazu multisensorycznego podstawą kształtowania obszarów rekreacyjnych, [in:] Metody oceny środowiska przyrodniczego, Wyższa Szkoła Pedagogiczna w Bydgoszczy, Bydgoszcz, 128 pp.

KOWALCZYK, A., 2007, Atrakcyjność turystyczna krajobrazu kulturowego, [in:] Znaczenie badań krajobrazowych dla zrównoważonego rozwoju, Uniwersytet Warszawski, Wydział Geografii i Studiów Regionalnych, Warszawa, pp. 121-132.
LISZEWSKI, S., 2007, Krajobraz miasta a warunki życia, [in:] Znaczenie badań krajobrazowych dla zrównoważonego rozwoju, Uniwersytet Warszawski, Wydział Geografii i Studiów Regionalnych, Warszawa, pp. 99-110.

MEYER, B., 2008, Krajobraz jako element atrakcyjności turystycznej obszaru, [in:] Studia krajobrazowe jako podstawa wtaściwego gospodarowania przestrzenia, eds A. Zaręba i D. Chylińska, Zakład Geografii Regionalnej i Turystyki Uniwersytet Wrocławski, Wrocław, pp. 119-126.

PIETRZAK, M., 2007, Istota, teoria i znaczenie praktyczne pojęcia "struktura krajobrazu", [in:] Znaczenie badań krajobrazowych dla zrównoważonego rozwoju, Uniwersytet Warszawski, Wydział Geografii i Studiów Regionalnych, Warszawa, pp. 311-326.

PLIT, F., 2007, Uwagi o nazewnictwie krajobrazów, [in:] Znaczenie badań krajobrazowych dla zrównoważonego rozwoju, Uniwersytet Warszawski, Wydział Geografii i Studiów Regionalnych, Warszawa, pp. 157-166.

Słownik języka polskiego, 1978, ed. M. Szymczak, Państwowe Wydawnictwo Naukowe, Warszawa.

Słownik języka polskiego, 2007, ed. M. Bańko, Wydawnictwo Naukowe PWN, Warszawa.

OSTASZEWSKA, K, 2002, Geografia krajobrazu. Wybrane zagadnienia metodologiczne, Wydawnictwo Naukowe PWN, Warszawa.

RICHLING, A., SOLON, J., 1996, 2002, Ekologia krajobrazu, Wydawnictwo Naukowe PWN, Warszawa.

SUCHODOLSKI, J., 2008, Kształtowanie współczesnej zabudowy miejscowości turystycznych w sudeckim krajobrazie kulturowym na przykładzie Zieleńca w Górach Orlickich, [in:] Studia krajobrazowe jako podstawa właściwego gospodarowania przestrzenia, eds. A. Zaręba i D. Chylińska, Zakład Geografii Regionalnej i Turystyki Uniwersytetu Wrocławskiego, Wrocław, pp. 187197.

WŁODARCZYK, B., 1999, Przemiany form aktywności turystycznej. Przykład krawędzi Wyżyny Łódzkiej, Łódzkie Towarzystwo Naukowe, Łódź, 194 pp.

WŁODARCZYK, B., 2009, Przestrzeń turystyczna. Istota, koncepcje, determinanty rozwoju, Wydawnictwo Uniwersytetu Łódzkiego, Łódź, 268 pp. 